\title{
Feasibility Analysis for the New Venture Nonprofit Enterprise
}

\author{
Gregory R. Berry
}

\begin{abstract}
This article explores the value of feasibility analysis for the pre-launch nonprofit enterprise. Similarities and differences between for-profit entrepreneurial ventures and nonprofit entrepreneurial ventures are outlined, and then the traditional format of feasibility analysis used by the entrepreneurial for-profit start-up is reviewed and analyzed. This four-stage analysis is then adapted to the needs of the nonprofit new venture enterprise. The benefits of doing a feasibility analysis for the nonprofit enterprise start-up are identified, and guidelines are suggested. An underpopulated research stream is identified and explained in this article for the start-up and early developmental phases of the nonprofit enterprise.
\end{abstract}

Keywords: feasibility analysis; nonprofit enterprise; nonprofit entrepreneurship; entrepreneurship; new venture launch; planning/research

\section{Introduction}

All new enterprises need some form of organization and structure that enables the entrepreneur to raise funds, to establish a strategic plan, and then to carry out tasks in service of that strategy. The creation of a new enterprise is the means by which entrepreneurs realize their entrepreneurial ambitions and personal goals. Significantly, these new ventures may be for-profit or nonprofit enterprises (Majumdar, 2008). Regardless of purpose, all organizations seek survival, success, and efficiency, often achieved through innovative and careful management of their operations and expenditure of resources. Forprofit firms usually seek to create profit by increasing their return on investment or by increasing market share, while nonprofit enterprises usually seek to increase their influence and scale of operation as they strive to assist in solving social problems or delivering socially important goods (Dees \& Anderson, 2003). Nonprofit enterprises take on a multitude of roles and do everything from housing to feeding the homeless to supporting the arts and education.
Yet, regardless of purpose or mission, about onethird of all new firms in the United States, including both for-profit and nonprofit enterprises, fail within the first few years of operation, while another significant percentage fail within four years (Barringer \& Gresock, 2008). An obvious and significant factor that contributes to new venture success or failure is planning, or lack of planning (Delmar \& Shane, 2003). There are many planning resources to assist established for-profit organizations including strategic, tactical, and functional planning tools, with most of these tools using financial and economic measurements to evaluate or judge ongoing performance. Fewer resources are available for pre-launch analysis and planning, but the two most common are the prescreening of new business ideas through feasibility analysis, and then the writing of a business plan (Barringer \& Gresock, 2008). Often little time is given for a careful and thorough examination of the merits of the idea before the business plan is written or the enterprise is launched, and although research is largely lacking regarding the outcomes of this lapse, this may be especially true for nonprofit enterprises.

For ease of concept and argument, this article is focused only on the nonprofit new venture, and not more generally on social enterprises, which could include both for-profit and nonprofit new ventures. The major distinction between for-profit and nonprofit enterprises is that they are two distinct forms of legal incorporation, defined by tax implication, financial considerations (including access to start-up and working capital), and ownership and governance structures. For-profit ventures seek to create economic wealth for their owners and investors, while nonprofits are banned from having profits even while having revenues, and so all revenue in the nonprofit is re-invested into the enterprise.

Though the distinctions between for-profit and nonprofit enterprises are clear at their extremes, it would be more accurate to view these distinctions between forprofit and nonprofit enterprises as being on a continuum. One end of the continuum has an absolute focus on profit 
generation, regardless of the means or consequences, and on the other end the focus is on the advancement of social well-being as the ultimate goal. These distinctions between organizations can be fuzzy, however, with most enterprises having some mix of the two objectives. Thus, some for-profits have a strong social-benefit presence, while some nonprofits are strongly aware of revenue and market share while maintaining and protecting their nonprofit status. These distinctions can become complicated and confusing, and thus this article will not cover the full range of social enterprises, but will focus only on the tax-exempt nonprofit. This distinction is relevant to this manuscript as the idea of feasibility analysis is usually present among for-profit ventures, regardless of the priority of their social focus, yet the feasibility analysis is often ignored by nonprofit enterprises.

A nonprofit enterprise is typically defined as an organization that uses resources in innovative or creative ways to explore and utilize opportunities to meet a societal need sustainability (Seelos \& Mair, 2005; Dorado, 2006). For the nonprofit enterprise, the creation and dissemination of social value is paramount, and the social mission is built directly into the business model. Nonprofit entrepreneurs form nonprofit enterprises to enable them to work toward changing or improving some condition in the world, either for a specific group of people or for society in general. For a nonprofit enterprise to be considered successful, it needs to be changing some aspect of the human condition or working toward solving a social problem. The work of a nonprofit enterprise is rarely finished as society's needs are rarely eradicated, and progress toward achieving these social goals is often very slow.

Nonprofit enterprises can be very different from for-profit enterprises both in process and outcomes, yet similarities are present as well. Value can be added to the nonprofit new venture enterprise by integrating mainstream entrepreneurship and new venture research knowledge (Peredo \& McLean, 2006; Weerawardena \& Sullivan-Mort, 2006).

In this article the value of feasibility analysis for the pre-launch nonprofit enterprise is explored. For context and framing purposes, similarities and differences between for-profit entrepreneurial ventures and nonprofit enterprise ventures are first outlined, followed by an examination of the traditional format of new venture for-profit feasibility analysis. This analysis is then adapted to the needs of the nonprofit enterprise, and the benefits of doing a feasibility analysis for the pre-launch nonprofit enterprise are identified. This research adds to the probability of success for the social enterprise through outlining practical and research-based considerations for the nonprofit entrepreneur to consider prior to the launch of their venture. An underpopulated research stream is also identified in this article, namely the use of feasibility analysis, especially in the start-up and early developmental phases of the nonprofit enterprise.

\section{Nonprofit Enterprise and For-profit Enterprise Share Some Common Characteristics}

New venture creation for both for-profit and nonprofit enterprises is a complex social process shaped in part by the personal characteristics and interests of the individual(s) starting the venture, as well as the context and environment surrounding the new venture (Steyaert \& Katz, 2004). The start-up entrepreneurial process for profit-seeking enterprises involves the identification, evaluation, and exploitation of opportunities to create new products or services for clients or customers such that the entrepreneur is able to obtain economic gains (Eckhardt \& Shane, 2003). The start-up process is essentially the same for the nonprofit enterprise except for a focus on outcomes such as social impacts or benefits instead of profitable financial or economic outcomes.

Nonprofit enterprises and for-profit enterprises both identify entrepreneurial commitment to the attainment of a mission as a means of identifying who is an entrepreneur (Sharir \& Lerner, 2006), and so commitment and passion are common characteristics of both the for-profit and nonprofit entrepreneur. Both types of entrepreneurs want "success" for their enterprises, and both types are concerned with costs and profits or revenue, but financial returns in the nonprofit enterprise are seen as a means to further their work, and not the goal of the work itself. Financial returns, from whatever source including donors, are still required for the nonprofit enterprise to maintain, sustain, and continue the work of the enterprise. Other similarities between nonprofit enterprises and for-profit enterprises include: a recognition that strong business practices are important; strong financial oversight including budgeting; a recognition that good strategic and tactical planning is based on good market and client information; and a belief that quality management skills including the ability to communicate clearly are necessary (Gartner, 1985).

Outcome-based quantitative indicators of enterprise progress or success in the for-profit enterprise include increased numbers of employees, increased output 
of products or services to the marketplace, growth of assets or market share, among other indicators (Dobbs $\&$ Hamilton, 2007). Net profit, equity enhancement, and growth of market share are the major indicators of growth or ongoing success suggested by researchers for the for-profit entrepreneur (Majumdar, 2008; O'Farrel $\&$ Hitchins, 2002). Most of these for-profit measures are not relevant to the nonprofit enterprise. Further, even these traditional quantitative measures are not shown to have a consistent impact on the growth or sustainability of for-profit enterprises, much less nonprofit enterprises (McKelvie \& Wiklund, 2010). Still, most nonprofit enterprise start-ups are focused on the development of managerial competencies and market-based attitudes to improve their operational efficiency and effectiveness, the same as with for-profit new ventures (Austin, Stevenson, \& WeiSkillern, 2006)

\section{Table 1. How Nonprofit Enterprise and For-Profit Enterprise are Similar}

Both enterprises is shaped by the personal characteristics, abilities, and interests of the entrepreneur

The choice of the product/service includes identification and exploitation of opportunities—both enterprises seek opportunities for underserved markets

Both enterprises seek to create new products and services for underserved markets

Both enterprises need entrepreneurial passion and commitment for start-up

Both enterprises seek success, although success is defined quite differently

Both enterprises are concerned with revenues and losses, although with different motivations

Both enterprises need strong business practices, including financial oversight

Both enterprises need good strategic and tactical planning that is based on client/market data and solid research

Both enterprises need strong communication skills from their leadership/managers both inside and outside the enterprise

Both focus on managerial competence to improve operational efficiency and effectiveness

\section{Nonprofit Entrepreneurship and For-profit Entrepreneurship Are Not Identical}

Nonprofit enterprises undertake activities to discover and exploit opportunities to enhance social well-being through the creation of new ventures or by innovatively managing existing organizations (Zahra et al., 2008). Social well-being can be understood as the improvement or creation of positive change in the quality of life conditions of constituents in a community, however that community is defined (Glover, 2012). It follows that a nonprofit entrepreneur is an individual who recognizes, organizes, and manages business opportunities resulting in the creation of social value and well-being (Certo \& Miller, 2008; Shaw \& Carter, 2007). The identification of potential benefit for the social sector often evolves from the entrepreneur's personal awareness of what they perceive to be a social problem (Casson, 2005), and perceived gaps in the social marketplace to solve these problems.

54 NEW ENGLAND JOURNAL OF ENTREPRENEURSHIP 
The initial activities of most nonprofit enterprises tend to be localized and small scale (Amin et al., 2002), and often occur in new contexts or emerging fields where unfulfilled social needs may seem more apparent (Maguire, Hardy, \& Lawrence, 2004).

The major difference between nonprofit enterprise and for-profit entrepreneurship is found in the purpose and outcomes desired and defined by the entrepreneur and the organization, and less in how these enterprises are managed and organized. Although nonprofit enterprises do not usually express a revenue motive, revenue must still be created to sustain the enterprise in continuing to reduce a social burden or initiating social change
(Austin et al., 2006). Nonprofit enterprises often focus on spreading the social good as widely as possible in order to maximize social change and directly address the problems that have been identified (Drayton, 2002; Chell, 2007). Economic revenue accumulation for the nonprofit enterprise is just the means to an end, with that end being social value creation and the achievement of long-lasting social change (Perrini et al., 2010). This single distinction alone is almost sufficient to differentiate the nonprofit from the for-profit entrepreneurial enterprise (Roper \& Cheney, 2005).

Table 2. Comparing Nonprofit Enterprises and For-Profit Enterprises

\section{Nonprofit Enterprises}

Focus on social impact and social benefit for a variety of stakeholders

Revenue is only the means to an end

Measures of growth include social impact or scale of social benefit (very difficult to measure)

Interest in growth is focused on the ability to spread the social benefit as widely as possible.

\section{For-Profit Enterprises}

Focus on profit above all else, almost exclusively for owners/stockholders

Profit for the sake of profit

Measures of growth include revenues and net profit, increases in equity and total assets, and market share (all easily measured)

Interest in growth is focused on maximizing profitability and stockholder/owner wealth

\section{The Benefits of Undertaking a Feasibility Analysis}

For sustainability, the nonprofit entrepreneur must develop the enterprise and manage resources with both commercial and social concerns in mind (Hynes, 2009). The traditional sequence recommended for pre-launch and analysis of any entrepreneurial venture is to first do an initial quick screen of the business concept or idea, then do the feasibility analysis, and then conclude the process with the writing of a business plan (Barringer \& Gresock, 2008). This is more difficult for the nonprofit enterprise than for the for-profit enterprise simply because the benefits from the operation of the social enterprise are often difficult to quantify, whereas the benefits created by a for-profit enterprise are easily judged using a variety of financial instruments. Although most nonprofits are internally clear about the benefits of the enterprise to a wide range of stakeholders, the enterprise may have difficulty in explaining or quantifying these benefits to those external stakeholders, particularly as different stakeholders may value different outcomes. Often the benefit of the nonprofit is measured in part by what didn't happen to clients or the community, and measuring the benefit of a non-occurrence is very difficult. The nonprofit has many stakeholders to satisfy, all with various needs and concerns, whereas the forprofit needs to satisfy only the owners of the firm, although satisfying other stakeholders perhaps enhances the owner's ultimate economic satisfaction. A serious consequence of this lack of clarity regarding the tangible benefits from 
the nonprofit enterprise is that obtaining financing from commercial institutions is almost impossible (Hynes, 2009), and may also create difficulties in gaining support from donors or institutions.

Competent planning is critical and aids the enterprise in multiple ways, including saving the entrepreneur countless hours. Multiple tasks, from budgeting to grant writing, require that the nonprofit enterprise makes plans for the future as well as the present. The act of planning fundamentally means thinking through what the enterprise is going to accomplish, simultaneously identifying needed resources, and then identifying activities to be undertaken in achieving these goals. The feasibility analysis aids in answering questions about the potential of a product or service in various markets, organizational and managerial capability, and financial prowess. Thus, the nonprofit enterprise starts with the initial identification of a service or product/project idea, then conducts the four-part feasibility analysis before determining if the writing of a business plan is warranted. The business plan is the final step of a comprehensive process, and incorporates most research and data already collected while doing the feasibility analysis.

If an entrepreneur gets caught up in the excitement that surrounds the identification of a new opportunity, careful analysis and planning may be given short-shift in an eagerness to bring the product or service to market (Barringer \& Gresock, 2008). Passion for the idea, and excitement regarding the benefits of the idea, are necessary for any start-up venture, but also something to be wary of. Careful front-end preparation and planning takes time and effort, and is essential in discovering flaws and issues early instead of later when they evolve into unsolvable problems. Proper evaluation will identify whether existing managerial and organizational competence is present, whether on-hand capital is sufficient not only for start-up costs but also operational costs until a break-even point is reached, whether the enterprise has all needed resources or access to these resources, and whether markets are not only available but are also sufficiently open to allow a new enterprise to enter the marketplace (Shah et al., 2013).

Decisions need to be based on data and careful analysis, and not on speculation or wishful conviction, and this is true for both for-profit and nonprofit enterprises. This data analysis can and should be done in advance of any large investment of resources including time, money, or energy. Some subjectivity is inevitable regardless of intent, but all data needs to be looked at and realistically analyzed, and not just the data that happens to confirm prior bias or preferred conclusions.

Without purposeful organizational and businessoriented practice, the social vision of the nonprofit enterprise may not be achieved, or perhaps achieved in the short-term but not be sustainable in the longer-term (Danby \& Jenkins, 2006). Thus, strategy and planning have an important role in carrying out action to support the mission of the social enterprise. Action is needed to achieve the objectives and goals set by the firm, regardless of the firm's resources and talent and financial strength. Burns (2007, p. 253) suggests that strategy as "just a linked pattern of actions," even as these actions constantly change and adapt to various situations and contexts, and at all levels of the enterprise. Strategies and choices for both the for-profit and nonprofit enterprise could include extending product lines or services, increasing marketing and sales activities, attracting new clients or customers, improving infrastructure or internal systems or service capacity, and changing or improving technological or information systems (Shah et al., 2013).

\section{Four-part Feasibility Analysis for the For-profit Enterprise}

Even with careful planning and analysis the entrepreneurial process is filled with uncertainty and unanswered questions (Ozer, 2003), and certainly with no guarantee of success. The process is often fraught with more questions than answers, and perhaps the "needed" questions are not being asked in the first place. The fundamental purpose of planning for any enterprise is to build a structure that is flexible enough to adapt to changes in the external environment, yet organizes the enterprise's activities and allocates resources in the most effective ways in pursuit of the mission. Consensus is needed in terms of "what" work to do, but then also needed in terms of "how" to do this work.

\section{Attempts at objectivity in the entrepreneurial} process are sometimes frustrated as personal conviction overwhelms analysis, yet brutal honesty regarding needed resources and required skills to achieve the goals of the enterprise is a must. The process itself needs to be easily understood, and yet must offer as complete an analysis as possible, and with unknowns clearly highlighted for future further examination. The feasibility analysis guarantees that the work done between the initial identification of

56 NEW ENGLAND JOURNAL OF ENTREPRENEURSHIP 
a business idea and then the launching a new venture goes beyond simply trying to determine if the product or service itself is good. Considerations need to include management ability and skill, marketing capability, a multitude of financial considerations including revenue streams and capital reserves, industry considerations and other factors (Allen, 2016).

Doing a quick overall screen should be done prior to starting a full-fledged feasibility analysis, and is particularly helpful in identifying weak or improbable ideas. Most proposed enterprises have identified strengths, but also have weaknesses, and these weaknesses need to be identified and mitigated prior to moving on. Plus, not all identified strengths and weaknesses are relevant for all proposed ventures. Personal networking skills, for example, may be critical for Project A but unnecessary for Project B. Some research suggests using a simple higher- or lowerpotential evaluation for the various factors being considered (Timmons \& Spinelli, 2004), seeking an overwhelming collection of high potential factors. The key is that all four sections of the feasibility analysis need to be briefly considered in the screen, and none ignored. Market-related issues are examined, as is competitive advantage or lack of advantage, managerial and financial resources, and overall potential is realistically determined. This is the first stage where new venture ideas may need to die prior to the entrepreneur spending valuable time and resources doing the feasibility analysis, and then creating a business plan, or worse, simply opening the enterprise then struggling to make it work and perhaps watching it fail.

The feasibility analysis will not be started unless the initial screen is strong and positive. The full feasibility analysis for a for-profit enterprise typically covers four areas: Product/service feasibility; Industry/market feasibility; Organizational feasibility; and Financial feasibility (Barringer \& Gresock, 2008). All four areas need to result in a positive feasibility - a positive result in only two or three out of the four areas in the feasibility analysis is to invite eventual disappointment, frustration, and wasted resources. Strength in one area does not compensate for weakness in other areas. The purpose of the feasibility analysis is to fully and honestly assess the potential merits of a business idea, and adjust the idea as necessary. Weaknesses identified early might be mitigated or fixed with added resources such as financial or human capital, expertise, or specific business experience. If the feasibility analysis is a "go" in all four areas, then the enterprise moves on to the business plan stage of the process, the final step in this pre-launch evaluation.

The next four sections examine the feasibility analysis for the for-profit new venture.

\section{For-profit Product/Service Feasibility Analysis}

Product/service feasibility is an assessment of the overall appeal of the product or service that is being proposed (Klink \& Athaide, 2006). This sometimes includes a concept test, when the product or service idea is shared with prospective customers to gauge customer interest. A potential product or service of huge importance or significance to the founders/entrepreneurs may have limited market potential; thus, the product/service analysis puts a more macro and realistic lens on the entrepreneur's vision or concept. If a service, what is the value added to the end user, and is it worth their time/effort/money for the user to take advantage of the service? Thought must be given to just how the product will be produced or the service will be delivered, and what other resources including infrastructure and organizational ability will be needed to make this happen, regardless of how great the product/service itself may be.

Most new ventures are short of surplus resources, underlining the need for sound preparation so that available resources are not wasted. Scale and scope for the new venture is analyzed as part of the product/service feasibility as well, perhaps resulting in the new venture starting with a focus on only $X$ instead of $X Y Z$, given the realistic appraisal of all resources available, market for the product/service, and overall ability of the entrepreneur to create/produce/deliver the product or service to the client or customer.

\section{For-Profit Industry/Market Feasibility Analysis}

The Industry/Market feasibility analysis considers general industry attractiveness, the possible identification of a niche market, and the openness of the marketplace to a new competitor (Allen, 2016). Most new enterprises want a growing market, or at least a market with growth being possible in a specific niche. Other factors contributing to the attractiveness of an industry include the extent to which an industry is important to the customer, the opportunity for higher operating margins, and whether an industry lacks competitors. Is there room for one more competitor, given that most markets are already being served at least to some extent? A niche position within a larger market represents a narrower group of 
customers with specific interests or needs that match the offerings and capabilities from the new venture (Markides, 2006). Most new ventures target a single segment or a specific market niche within the industry. Importantly, given that the existing competition may have certain established competitive advantages in terms of available capital, established clients and markets, and established supply chains both in and out of the enterprise, where is the possible advantage for the new venture? Do the main competitors exhibit particular strengths that could overwhelm the new venture's resources, or alternatively do these main competitors exhibit weaknesses that could present the new venture with an opportunity to create a specific competitive advantage? Is there an underserved niche where the new venture's capabilities will fit nicely?

Porter's Five Forces (1980) model is often used at this stage of the feasibility analysis. Porter (1980) identified five threats to any venture: strength and number of suppliers; alternative choices available to the consumer/user; threat of new entrants, threat of substitute products; and threat from the industry itself in terms of aggressive competition. In an ideal world the new venture would realize unlimited suppliers, limited choice or options for the client/user, limited possibilities for new entrants or substitutes, and all in a stable yet growing and fragmented industry/marketplace.

\section{For-profit Organizational Feasibility}

Organizational feasibility is conducted to determine whether a proposed new venture has sufficient management prowess, organizational competence, and non-financial resources to launch and manage the proposed new venture successfully. Personal commitment may be a given, but the entrepreneur also needs to have a realistic and factual understanding of the chosen market niche, and further understand how his/her talents and the product/service of the new venture "fits" in that niche. Realistic self-judgment is critical here for the founder/entrepreneur, and overestimating personal ability/skill/knowledge while underestimating these same qualities in competitors is self-defeating. Other factors to consider in the organizational feasibility analysis include facility availability, availability of quality staff, and even the receptivity of the community (potential clients or volunteers perhaps) to the proposed venture (Barringer \& Gresock, 2008).
Strategic planning in small entrepreneurial firms is mainly guided by the personal vision coupled with the personality and character of the chief executive (Wood \& Joyce, 2000), and so success or failure is highly dependent on the founder. Again, reflective honesty is required for self-analysis on the part of the entrepreneur. In a perfect world characteristics of the founder/ entrepreneur could include background and experience, proven capability in a specific or a related market, relevant education, and general managerial competence (Barringer et al., 2005). Personality and mindset of the entrepreneur play a role (Boeker \& Wiltbank, 2005; Kor, 2003; Wijewardena et al., 2008), although sometimes over-emphasized relative to the more pragmatic background and experience characteristics.

\section{For-profit Financial feasibility Analysis}

The most important issues to consider in the financial feasibility analysis are total start-up cash needed, and the overall financial attractiveness of the investment (Barringer \& Gresock, 2008). Funding is needed not only for the physical start-up but also for the operation of the new venture until a break-even point is reached, oftentimes months or perhaps even years into the future. The financial feasibility analysis explores and explains where initial and ongoing funding will come from. For a for-profit enterprise, these evaluations of needed start-up costs and timelines for break-even analysis usually use the new venture's projected return on assets or sales. For new enterprises this is a best guess based on the rigorous collection of industry and specific market data. The softer the data the more likely the financial projections created will not be accurate.

The financial analysis uses data and information collected during the prior steps in the overall feasibility analysis. The fundamental question is: Assuming the ability to produce the product or service, is there a market of sufficient size that will purchase the product or service at a price that will allow for the ongoing operation of the enterprise? The financial feasibility is focused on costs and potential revenues from start-up, over time, and with some added considerations given to potential growth or the development/expansion of the enterprise. 


\section{Table 3. Questions Asked During Feasibility Analysis}

\section{Product/Service Feasibility Analysis}

Is value added for the client/customer?

Is the product or service important to the client/customer?

Is the trade-off in time, effort, and cost worth it to the client/customer?

How were these needs of the client/customer identified and quantified?

What is the scope and scale of the new venture to meet these identified needs?

Does the new venture have the ability to create and deliver these products/services?

\section{Industry/Market Feasibility Analysis}

Is the market growing or shrinking, or stable?

Is there a niche space or player role for the new venture?

Is there room for advantageous operating margins ... thus sustainability?

Is the marketplace or niche crowded or sparse in this specific geographic area?

Is there competitive advantage or disadvantage for the venture in this market?

\section{Organizational Feasibility Analysis}

What specific expertise, education, and knowledge does the founding team have?

What non-financial "other" resources does the new venture have?

Is there potential to attract quality staff or key employees?

Is there potential to find a quality and cost-efficient facility?

Does the new venture have any networked support from the local community?

\section{Financial Feasibility Analysis}

What are the start-up costs?

When is the break-even (BE) date?

Does the new venture have sufficient funds to survive while awaiting the BE date?

Where does financial support come from?

How confident is the new venture of sustained revenue from all sources over time?

\section{Adapting the Four-phase Feasibility Analysis for the Nonprofit Enterprise}

All four parts of the feasibility analysis are required and useful for the nonprofit enterprise. Similar to the forprofit enterprise the evaluation of all four parts must result in positive conclusions, and if not initially positive, the shortcomings must be mitigated and resolved.

The nonprofit enterprise can damage itself severely by being overly optimistic in any of the four sections of the feasibility analysis. Worse, ignoring any of the four sections leaves open the possibility on an undiagnosed fatal flaw, and so the four-part analysis goes beyond optimistic thinking and dreams. This is where business ideas or proposals need to be fully understood, not because the venture doesn't have generic merit but because either the market for the program/service is too small to begin with, 
or because this specific group of entrepreneurs simply does not have the organizational strength or financial resources to bring the concept to sustainable creation. Donor or revenue support is also a critical factor for nonprofits and must be fully understood prior to launch. In the nonprofit enterprise arena almost all ideas are "good" in terms of creating a social benefit, but are they sustainable and feasible as ongoing operations or enterprises?

The nonprofit entrepreneur must be clear why the enterprise should exist, what the objectives and goals might be, and how the nonprofit will achieve these objectives and goals using available resources and talents. Both short-term and long-term goals need to be outlined, preferably with timelines and benchmarks set, which may evolve over time. What resources are needed, for example, to meet short-term goals, especially for start-up costs and immediate operations costs? What are the key resources needed immediately including money, key personnel and volunteer availability, specific skills needed from these employees/volunteers, and the type of physical space needed to start and then carry out the activities of the enterprise? Even this initial screen may provide some detail and guidelines for future work and planning, but the feasibility analysis will more specifically identify serious flaws, if any, in the earlier evaluation. The earlier these issues and problems are identified the sooner they can be rectified, or resolved with a fundamental re-think of the nonprofit venture itself.

After the screen, and then the feasibility analysis, the business plan is the final pre-launch document. The hard work and data collection is undertaken for the feasibility analysis. Goals and benchmarks have been identified. Not only are general plans and strategies set, but assumptions are also acknowledged and defined, and so if a benchmark is missed in Plan A because of faulty assumptions, then Plan B or Plan C has already been at least partially considered, with adjustments then more easily made. Outside the firm, the business plan introduces potential stakeholders including potential benefactors to the nonprofit opportunity the firm is pursuing. Inside the enterprise, the feasibility analysis is done with a skeptical view, almost asking, "Why won't this work?" whereas the business plan often presents a more positive story along the lines of "This will work and will be great."The feasibility analysis could be viewed as the real work behind the scenes, while the business plan is the glossy production under the lights. Still, the business plan needs to be based on solid data and analysis rather than on speculation and optimistic platitudes, and is factually and fundamentally based on the feasibility analysis.

\section{Transitioning the Feasibility Analysis from the For-profit to the Nonprofit Enterprise}

Consistent with research on entrepreneurial start-ups (Ucbasaran, Westhead, \& Wright, 2001), opportunity formalization through the writing of the business plan for the nonprofit enterprise is a crucial step in the overall startup new venture process. Milestones are identified, and are critically important in scheduling and sequencing the work to be done. The resources to be expended at certain times in the start-up process are identified and potentially sourced. Given the difficulty to show the soundness of a nonprofit project on the basis of well-established economic performance indicators (Doraldo, 2006), and the difficulty of documenting actual social benefits or the lack of negative social consequences, the feasibility analysis followed by the business plan is crucial for the nonprofit enterprise. The feasibility analysis for the nonprofit enterprise means more than just asking the questions, but includes the documentation of the research and answers resulting from these questions.

The next four sections translate the for-profit feasibility analysis into the adapted analysis for the nonprofit enterprise.

\section{Product/Service Feasibility Analysis for the Nonprofit Enterprise}

Nonprofit enterprises are generally interested in increasing positive impact on society or a community through the providing of a service or project or product. Unlike the for-profit enterprise, the nonprofit enterprise is less focused on generating revenue and more focused on the social benefit of their operations. Still, as with for-profit enterprises, there must be an identified and documented consumer/client need for the product/service in the first place, and value created for the client/consumer, or the product/service will be ignored. The product/service must have value or need to a sufficient number of clients, and must be worth their time and effort to purchase or use the product or service. The product/service feasibility analysis includes: market assessment asking "Will anyone use this product?"; technical and operational assessment asking "Can this product be made or served?"; and business assessment asking "Can the product/service generate revenue or sufficient donor interest to be viable and sustainable?" (Barringer \& Gresock, 2008). Other necessary

60 NEW ENGLAND JOURNAL OF ENTREPRENEURSHIP 
questions include: Are there any identified and clear trends regarding what the future may bring? Does the product or service exist in a context of growing or continuing need, given cutbacks or changes in government support, for example? Does the nonprofit enterprise have the operational and organizational ability to produce this product/service, and get this product/service to market such that it provides added value to identified clients or users?

\section{Industry/Market Feasibility Analysis for the Nonprofit Enterprise}

Societal need seems endless, and thus there is a constant supply of individuals and groups who are underserved or ignored by commercial ventures. The marketplace is usually ripe for more nonprofit enterprises. Yet, regardless of merit or the goals of the enterprise, all enterprises require and use resources; time, money, energy, and human capital must be found and replenished as they are expended. Given a constant or continuing market need, the basic task for the nonprofit enterprise is often seeking and finding resources and staff abilities, not in seeking clients or consumers as is usually the case for the for-profit enterprise.

Many nonprofit enterprises operate with a large market need, without financial support from this market_-running a homeless shelter or food kitchen are examples. External funding sources are often necessary and critical for the survival of the nonprofit enterprise. This business model is different when compared to the for-profit firm where success or failure is found exclusively in the marketplace, and external operational funding separate from the consumer marketplace is extremely rare. For some nonprofit enterprises, the "marketplace" of significance is the funding-grants marketplace, with the purpose of the nonprofit enterprise somewhat removed from the critical function of fundraising. Generally, when surveying the external environment, questions asked by the nonprofit enterprise include: Are other enterprises providing similar services in the community? What are the demographic trends in the area? What are the trends in the fundraising arena in which our nonprofit operates? How stable are funding sources, including government agencies? As with the for-profit enterprise, the industry/ market for the social enterprise must be large enough to allow at least one more player, and the social enterprise needs to be strong enough in all four sectors of the feasibility analysis to compete in the industry/market.
Therein lies a fundamental challenge for the entrepreneur-how to align the nonprofit enterprise to address and satisfy the changing needs of their consumer/ client stakeholders while at the same time maintaining a revenue stream from external stakeholders sufficient to sustain the enterprise (Hynes, 2009). This alignment is easier for the for-profit entrepreneur as the significant stakeholder is the owner/stockholder, and most if not all organizational activities are focused on creating a business with positive profit generation for that owner/ stockholder. Multiple stakeholders have to be considered in the nonprofit enterprise because there are no owners, and the enterprise includes employees and clients, as well as other stakeholders, such as funding organizations, volunteers, collaborators or partners, and a large network of secondary supporters. These multiple stakeholders may not share common goals or agendas, yet all need to be satisfied, at least to some degree (Freeman, 1984). Most nonprofit entrepreneurs need a multi-stakeholder focus and so the task of setting business objectives becomes more complicated, and may require trade-offs between social and commercial commitments to maintain stability and sustainability (Doherty et al., 2009).

The industry is the specific environment/context in which a new enterprise operates, and in which they offer their products or services. The nonprofit enterprise must know its industry/environment well because this understanding is fundamental to entering the market effectively in the first place and grow within the market once established. This context will determine in part the potential for success in meeting the needs of clients, and/or finding donor support. It is not always easy to determine where any specific industry begins and ends, and the nonprofit entrepreneur may discover that the new enterprise crosses or blends with several other industries and environments.

Marketing, when applied to the nonprofit enterprise, means fully understanding the needs of your clients as well as your donor stakeholders, and then managing your organizational response to meet those needs and expectations. This is more than publicity efforts or image management, although they may play a role. In terms of the analysis of competitors, at least for the funding agencies, there is a need to know exactly how your organization will be different from others in the field, and why that difference deserves to be funded. Bull (2007) indicated the need to define specifically the social value 
and the impact of social change as a means of developing suitable measures of nonprofit enterprise growth. This definition and proving of social value and impact can be extremely difficult-how does one measure the lack of a negative outcome? Marketing for the nonprofit enterprise is the process of connecting consumers to services and products, and is just as crucial to the success of nonprofit enterprises as it is to for-profit enterprises. Aside from connecting with clients, the nonprofit enterprise also needs to connect funding agencies or funding individuals with the mission and stated objectives of the enterprise. Without clients using the services/projects/products of the enterprise, the nonprofit enterprise will almost certainly find itself without external funding sources as well.

\section{Organizational Feasibility Analysis for the Nonprofit Enterprise}

Employees are a key resource for achieving the mission or the strategy of most enterprises. Imperatori and Ruta (2006) suggest that the success of the entrepreneurial enterprise is dependent upon its ability to attract and retain the correct blend of complementary skills to those of the founding entrepreneur. Insuring high-quality work from those employees is also critical (Lyon \& Fernandez, 2012). The members of the organization need to know and understand the organization's purpose - this is essential in making organizational decisions, and provides a guide for the daily behavior of all concerned. Understanding the purpose of the enterprise is also a fundamental need when asking for donor money, or recruiting board or volunteer members, hiring and motivating staff, and/ or publicizing activities. Yet, beyond having committed employees and/or volunteers, the enterprise needs to have the infrastructure and management knowledge to run the business side of the enterprise itself as well as the operational ability to deliver the product/service.

Who are the founders/employees/volunteers, or other providers of the service or product? Who has decision-making responsibility, and what is the process for accountability? The founders of some nonprofits do not come from the business community, nor do they have much experience in managing and running a business, handling staff, or understanding financial records. Although a formal business education or background is generally acknowledged as a necessity when starting a for-profit enterprise, it seems more acceptable to not have such a background when starting a nonprofit enterprise. Allen (2016) suggests that a successful new venture team must have one or more members of the core team with experience in the chosen industry or environment, solid contacts in the field, and also that the leadership team's expertise covers the key functional areas of the business, especially finance, marketing, and operations. Many of these traditional business abilities and concerns may seem secondary to the social mission of the enterprise, and may even seem secondary to those running the enterprise, but are necessary for operational sustainability.

Because there are multiple stakeholders associated with the nonprofit enterprise, the explanation of the social or financial benefits created by the enterprise also becomes more complicated. For the nonprofit what is important to one stakeholder may be irrelevant to another, yet all stakeholders need to be considered, at least to some extent (Freeman, 1984). As an example, government agencies may be a critical stakeholder for the nonprofit enterprise, and may be very interested in documentation of product/service delivery, whereas the employees of the enterprise may consider these expectations as only bureaucratic busywork, and clients of the enterprise may not even be aware of these expectations, much less care. The community, the media, the local business and social community, and others are all stakeholders of the nonprofit enterprise, along with clients and employees and volunteers. This is a much different mix from most forprofit enterprises. A for-profit enterprise may have it easier in that the established economic and financial measures are the accepted assessment tools. This concern with multiple stakeholders carries over into the examination of the organizational feasibility analysis. As an example, the founding entrepreneur may have brilliant skills when dealing with clients or users of the product/service, but less than adequate skills or even interest in dealing with the paperwork required for ongoing funding support. The nonprofit entrepreneur wears many hats by necessity, and failure in any major role or in dealing with a major stakeholder may curtail the enterprise. In addition to being qualified to achieve the social mission, the nonprofit entrepreneur needs to consider and feel confident about management, fundraising, and communication skills, or be willing to delegate these tasks to a skilled employee.

One organizational feasibility concern for the nonprofit is staffing, and the use of volunteers. Almost no one volunteers to work without payment in the forprofit world, yet volunteers are often the lifeblood of the nonprofit enterprise. Without people who are willing

62 NEW ENGLAND JOURNAL OF ENTREPRENEURSHIP 
and able to give freely of their time and expertise, many nonprofits would be so limited in their ability to fulfill their mission that they would likely close. One issue may be that when relying on volunteers, scheduling depends on a number of other things in the volunteers'lives, and the time people can commit to the organization often takes on a lower priority as compared to family or wage-work. Regardless of the enterprise's purpose or intent, a nonprofit enterprise has a specific employee class with unique issues.

Along with volunteers, other significant stakeholders include the advisory committee or board. Committees and boards are an excellent way for the nonprofit to bring respected members of the community into the organization of the nonprofit, realizing that these people want to support the nonprofit enterprise but are perhaps too busy to commit to more full-time tasks. As well, professional advisors are significant stakeholders as they may provide information and skills perhaps not present on the nonprofit's employee roster. These advisors can play devil's advocate to counter the sometimes-enthusiastic ideas the entrepreneurs may have in their enterprise, offering a reality check. Among others, accountants, bankers, lawyers and insurance agents can all play the advisor role.

\section{Financial Feasibility Analysis for the Nonprofit Enterprise}

Unlike the for-profit enterprise in which individual owners, partners, or shareholders may personally benefit from the financial performance of the organization, no individual directly benefits from any revenue generated by the nonprofit enterprise. Rather, the money considered "profit" in the for-profit enterprise is turned back into the organization in the nonprofit enterprise, either as program money to continue the work, or as reserve funds for future projects/programs. Sometimes nonprofit enterprises charge clients a fee for what they do, while other nonprofits may enter into contracts with a city or county to provide services to residents, while still other enterprises are fully funded through their donor network. Still, nonprofits can and do earn money, and so hire staff, engage consultants and other professionals, and operate like other business organizations. An important distinction is that the nonprofit is a tax-free organization, perhaps dependent on external donations, and that salaries or fees of employees must be established as set amounts and are not dependent on other financial calculations such as profit or market share.
Revenue from operations is often supplemented with revenue from other funding sources, and many nonprofit enterprises would not survive without external sources of revenue. The concern with social value and the concern with profit generation therefore is not mutually exclusive, and the challenge is to ensure that a sufficient and suitable mix of financial and social concern is realized (Hynes, 2009). Because most nonprofits serve a defined need in the community, taxdeductible donations are an important revenue source, and so an enterprise struggling to find support and donations may assume this is a sign that their ideas need to be refined, or at least that their communication and funding message needs to be improved.

Nonprofit enterprises are expected to spend prudently and honor the trust placed in them by their donors, and so they also need to be good at budgeting and living within their means. Developing budgets is more than just tweaking the financial records from prior years, and assists the social enterprise with program planning, grant-writing, and evaluation. Stability and continued funding are the goals of competent budgeting in the nonprofit enterprise, and the enterprise needs to keep competent records and base decisions on accurate financial information to achieve that stability. Good budgets are realistic and are based in part on realistic assessments of the resources the nonprofit enterprise can earn and raise. Cash-flow projection estimates not only show how much money will be received and spent over the course of a program or year, but also when the enterprise will receive and spend these funds (Hynes, 2009). One key for nonprofit enterprises is often found in obtaining nonprofit tax status for the organization in the first place, and this alone is a major accomplishment.

Ensuring that the social benefit to clients can be sustained at the same time as keeping the organization economically viable remains a constant challenge. This could be seen as an opportunity to serve a "double bottom-line" - a simultaneous blend of financial and social returns (Doherty et al., 2009). The revenue stream must be strong and consistent enough to sustain the enterprise over time - when resources are used they must be replenished, thus a need for business ability along with the commitment/passion for the mission. 


\section{Table 4. Questions Asked During Feasibility Analysis for a New Venture Nonprofit}

\section{Product Service Feasibility Analysis in the Nonprofit}

What is the value added to the client/customer?

Is a similar product or service offered by for-profit or other nonprofit enterprises?

Does the enterprise have the needed resources to produce this product/service?

Is the product/service provided in a safe and convenient manner given lack of resources or transportation

by some clients and customers?

Is the revenue stream strong enough to support the sustainability and continuation in providing

this product/service?

Is the need for this product or service growing, declining, or stable?

\section{Industry/Market Feasibility Analysis in the Nonprofit}

Although client need may be a given, what other resources are needed to enter the market including time/money/energy/skills/human capital?

Can the market itself provide some needed capital or revenue, or is the new venture completely dependent on government contracts or donor support?

What are the general demographic trends in the area-favorable for the new venture?

Who are the major stakeholders who must be satisfied?

What other stakeholders should be satisfied if possible?

Can the social goals of the new venture be clearly identified and explained?

\section{Organizational Feasibility Analysis in the Nonprofit}

Are volunteers or skilled potential employees available?

Are the objectives of the new venture clear and stimulating so as to gather support?

Who makes the decisions about the "what" and the "how" of the organization?

Are there available leadership and management skills for operational success?

Is the core management team capable of covering the areas of finance, marketing, and operations, along with other core management and communication skills?

Who will or can deal with the myriad of stakeholders involved?

Who will or can deal with managing and motivating volunteers and employees?

Is the board competent to offer advice in all four areas of the feasibility analysis?

\section{Financial Feasibility Analysis in the Nonprofit}

Who will set up a bookkeeping system sufficient to withstand rigorous audit?

Who is responsible for fundraising and proper accounting for all funds generated by the new venture enterprise?

Who will organize and obtain the nonprofit legal status, and then monitor behavior and practice to insure this status is maintained?

Is there a funding or grant "marketplace" for the new venture?

How stable are the funding sources?

Who will manage and establish budgets?

64 NEW ENGLAND JOURNAL OF ENTREPRENEURSHIP 


\section{Academic Contributions and Limitations}

This article offers three academic contributions. First, the article offers a specific outline for how to use the for-profit feasibility analysis for the nonprofit new venture. This outline might also be useful, at least in part, in other social enterprises, including for-profit social enterprises. The second contribution suggests a more theoretical base for examining the nonprofit. A focus on stakeholder analysis emerged during the exploration of using feasibility analysis in the nonprofit, and indeed impacted the awareness of different forces present in the nonprofit. A significantly broader stakeholder group is apparent in the nonprofit enterprise as compared to the for-profit new venture start-up. With the removal of owners or investors as the most significant stakeholder, other stakeholders assume greater importance, and thus have greater impact on the management and control of the nonprofit. The third contribution is more practical, but related to the second. The need and ability to deal with multiple stakeholders in the nonprofit is worthy of further research, especially when looking at the leadership or management of the nonprofit. This awareness suggests related topics for further research and should inform teaching at the university level regarding nonprofit management.

This article also has some limitations. It is a conceptual and theoretical piece, based on a literature review of entrepreneurial new ventures, combined with ongoing conversation and peripheral practice with those in the nonprofit realm. Thus, no quantitative data is offered. It seems unlikely that "proving" the benefit of feasibility analysis for the nonprofit is even possible given the difficulty of establishing control groups. However, case analysis, if started at the concept stage of start-up, may offer a possibility in terms of collecting data. Interviews post start-up with nonprofit entrepreneurs would likely offer some depth in terms of what the nonprofit entrepreneur perhaps "wished" they had done at an earlier date, but even that is difficult as one cannot easily measure the benefits or consequences of a non-action. If errors in planning or execution can be identified by these respondents, then perhaps these errors could have been identified earlier, had the feasibility analysis been done. Thus, this article offers the potential benefits of doing the feasibility analysis for the nonprofit as an extrapolation from the extant entrepreneurial feasibility analysis literature, and not based on data.

\section{Personal Nonprofit Entrepreneur/Practitioner Benefit of Doing a Feasibility Analysis}

There are many suggestions in this article as to how the nonprofit entrepreneur would benefit from doing a feasibility analysis of the new venture. Highlights include:

- The feasibility analysis "forces" the nonprofit entrepreneur to do all four parts of the analysis. This will not resolve all questions or problems but does make a significant contribution, and likely raises questions that might have been missed otherwise.

- The feasibility analysis "forces" the nonprofit entrepreneur to collect data and do careful research on all four sections of the feasibility analysis, all this prior to the business plan, and prior to the start-up itself.

- Given that the feasibility analysis is an internal document, there is no benefit whatsoever in being overly optimistic or unrealistic. Honesty and realism are the hallmarks of the feasibility analysis. The only one damaged by unrealistic analysis is the entrepreneur him/herself.

- One or two months spent on research for the feasibility analysis may save years of aggravation and frustration resulting from an unwise new venture start-up.

- The organizational feasibility encourages realistic selfassessment on the part of the entrepreneur, and may even identify expectations and aspects of the future operation that are impossible to implement given experience and background.

- The feasibility analysis offers an early view of gaps in needed resources, be that financial, experiential, or ability - gaps between what is and what-needs-to-be are identified.

- Pre-launch planning is commonly top heavy in consideration of client need and product/service identification and consequently much less time is spent on organizational, operational, and financial ability to manage or lead the enterprise, and the feasibility analysis not only raises these needed questions but also offers balance between the sections.

- The feasibility analysis places some focus on the long-term sustainability of the venture, beyond the immediate start-up process.

- The feasibility analysis encourages a focus on the "how" instead of just the "what." 


\section{Conclusion}

The nonprofit enterprise benefits from doing an entrepreneurial feasibility analysis for four main reasons.

First, the nonprofit enterprise can sharpen its focus by fully exploring the market potential of their products/ services/programs, and by perhaps disposing of their less competitive or significant offerings. This reduced but sharpened focus in the market/service offering should remove some of the uncertainty regarding the purpose and mission of the new venture. Under a more focused mission in the short term, while maintaining a broader long-term focus, products or projects or services can be added as needed or supported at some later date. Realistically, the new venture nonprofit enterprise cannot do everything it may want to do, at least in the beginning.

Second, as resources are scarce for almost all start-ups, the improved focus allows a more effective and efficient use of these resources, and should improve the timeliness of finding and spending resources including time, money, and energy. A greater awareness of the marketplace and the competitive environment may allow for more collaboration with other nonprofits or social enterprises, and perhaps even a greater sharing of resources, thus enhancing capability and effectiveness.

Third, as markets are more closely defined, and niches and sub-markets better understood after the feasibility analysis, the nonprofit enterprise can increase its potential impact by developing specific strategies for these more narrowly defined high-potential programs. It could happen that the larger initial concept is scrapped, and projects initially more subsidiary are approved, given the realistic appraisal of current resources and organizational ability as determined by the analysis. A tighter focus should also realize a less stressed operation, as resources are used more effectively and efficiently from the very start of the new venture.

Fourth, through the financial feasibility analysis the need for additional donor organizations may be defined early instead of perhaps too late, and the ability to generate additional earned revenue from current programs or from entirely new activities may become apparent as well. The premise that "if you build it they will come" is faulty in the funding marketplace. The nonprofit funding marketplace usually operates on fixed schedules, and examines potential funding options a year or more in advance of actual funding.

The feasibility analysis aids the nonprofit enterprise in all aspects of its planning, and thus aids the enterprise in reaching a sustainable position in its industry and marketplace. The new venture nonprofit enterprise is indeed an entrepreneurial new venture, and thus should use all the tools in the entrepreneurial toolkit to ensure the very best opportunity for success and the resultant spreading of the social benefit.

\section{REFERENCES}

Allen, K.R. (2016.) Launching new venture: An entrepreneurial approach. Boston, MA: Cengage Learning.

Amin, A., Cameron, A., \& Hudson, R. (2002.) Placing the social economy. London: Routledge.

Austin, J., Stevenson, H., \& Wei-Skillern, J. (2006.) Social and commercial entrepreneurship: Same, different or both? Entrepreneurship and Regional Development, 12, 91-110.

Barringer, B.B., \& Gresock, A.R. (2008.) Formalizing the front-end of the entrepreneurial process using the stage-gate model as a guide. Journal of Small Business and Enterprise Development, 15(2), 289-303.

Barringer, B.R., Jones, F.F., \& Neubaum, D.O. (2005.) A quantitative content analysis of the characteristics of rapid-growth firms and their founders. Journal of Business Venturing, 20(5):

Boeker, W., \& Wiltbank, R. (2005.) New venture evolution and managerial capabilities.

Bull, M. (2007.) Balance: The development of a social enterprise business performance tools. Social Enterprise Journal, 3(1), 49-66.

66 NEW ENGLAND JOURNAL OF ENTREPRENEURSHIP 
Burns, P. (2007.) Entrepreneurship and small business, 2 ${ }^{\text {nd }}$ Edition. New York, Palgrave MacMillan.

Casson, M. (2005.) Entrepreneurship and the theory of the firm. Journal of Economic Behavior and Organization, 58, 327-348.

Certo, S.T., \& Miller, T. (2008.) Social entrepreneurship: Key issues and concepts. Business Horizons, 51, 267-271.

Chell, E. (2007.) Social enterprise and entrepreneurship: Toward a convergent theory of the entrepreneurial process. International Small Business Journal, 25, 5-26.

Danby, L., \& Jenkins, H. (2006.) Applying sustainability indicators to the social enterprise business model. International Journal of Social Economics, 33(5/6), 411-431.

Dees, J.G. (2008.) Developing the field of social entrepreneurship. Report from the Center for the Advancement of Social Entrepreneurship, Duke University.

Dees, J.G. \& Anderson, B.B. (2003.) Sector bending: Blurring the lines between nonprofit and for-profit. Society (Social Sciences and Modern Society), 41(1), 16-27.

Delmar, F. \& Shane, S. (2003.) Does business planning facilitate the development of new ventures? Strategic Management Journal, 24(12), 1165-1186.

Dobbs, M. \& Hamilton, R.T. (2007.) Small business growth: Recent evidence and new directions. International Journal of Entrepreneurial Behavior and Research, 13, 296-322.

Doherty, B., Foster, G., Mason, C., Meehan, J., Rotheroe, N., \& Roybce, M. (2009.) Management for Social Enterprise. London: Sage.

Doraldo, S. (2006.) Social entrepreneurial ventures: Different values so different process of creation, no? Journal of Developmental Entrepreneurship, 11, 319-343.

Drayton, W. (2002.) The citizen sector: Becoming as entrepreneurial and competitive as business. California Management Review, 44, 120-132.

Eckhardt, J.T., \& Shane, S.A. (2003.) Opportunities and entrepreneurship. Journal of Management, 29, 333-349.

Freeman, R.E. (1984.) Strategic management: A stakeholder approach. Boston: Pitman.

Gartner, W.B. (1985.) A conceptual framework for describing the phenomenon of new venture creation. Academy of Management Review, 10, 696-706.

Glover, Y. (2012.) Organizational development and social entrepreneurship: Do well by doing good. American Journal of Management, 12(2/3), 117-122.

Hynes, B. (2009.) Growing the social enterprise-issues and challenges. Social Enterprise Journal, 5(2), 114-125.

Imperatori, B., \& Ruta, D. (2006.) Organizing a social enterprise. In Perrini, F. (Ed.), The New Entrepreneurship; What Awaits Social Entrepreneurial Ventures? Cheltenham: Elgar, pp. 105-121.

Klink, R.R. \& Athaide, G.A. (2006.) An illustration of potential sources of concept-test error. Journal of Product Innovation Management, 23, 359-370.

Kor, Y.Y. (2003.) Experience-based top management team competence and sustained growth. Organizational Science, 14(6), 707-719.

Lyon, F., \& Fernandez, H. (2012.) Strategies for scaling up social enterprise: Lessons from early years providers. Social Enterprise Journal, 8(1), 63-77.

Maguire, J., Hardy, C., \& Lawrence, T.B. (2004.) Institutional entrepreneurship in emerging fields: HIV/AIDS treatment advocacy in Canada. Academy of Management Journal, 47, 657-679. 
Majumdar, S. (2008.) Modelling growth strategy in small entrepreneurial business organizations. The Journal of Entrepreneurship. 17(2), 157-168.

Markides, C. (2006.) Creativity is not enough: ICT-enabled strategic innovation. Europeon Journal of Innovative Management, 9, 129-148.

McKelvie, A., \&Wiklund, J. (2010.) Advancing firm growth research: A focus on growth mode instead of growth rate. Entrepreneurial Theory and Practice, 34, 317-351.

O'Farrel, P.N.O., \& Hitchins, D.M. (2002.) Alternative theories of small firm growth. In M.F. Krueger (ed.), Entrepreneurship: Critical Perspectives on Business and Management,136-160. London and New York: Routledge.

Ozer, M. (2003.) Using the internet in new product development. Research Technology Management, Jan/Feb, 10-16.

Peredo, A.M., \& McLean, M. (2006.) Social Entrepreneurship: What awaits social entrepreneurial ventures? Journal of World Business, 41, 56-65.

Perrini, F., Vurro, C., \& Costanzo, L.A. (2010.) A process-based view of social entrepreneurship: From opportunity identification to scaling-up social change in the case of San Patrignano. Entrepreneurship \& Regional Development, 22(6), 515-534.

Porter, M. (1980.) Competitive strategy: Techniques for analyzing industries and competitors. New York: Free Press.

Roper, J., \& Cheney, G. (2005.) The meaning of social entrepreneurship today. Corporate Governance, 5(3), 95-104.

Seelos, C., \& Mair, J. (2005.) Social entrepreneurship: Creating new business models to serve the poor. Business Horizons, $48,241-246$.

Shah, S.F., Nazir, T., \& Zaman, K. (2013.) A literature review on growth models and strategies: The missing link in entrepreneurial growth. Management Science Letters, 3, 2189-2200.

Sharir, M., \& Lerner, M. (2006.) Gauging the success of social ventures initiated by individual social entrepreneurs. Journal of World Business, 41, 6-20.

Shaw, E., \& Carter, S. (2007.) Social entrepreneurship theoretical antecedents and empirical analysis of entrepreneurial process and outcomes. Journal of Small Business and Enterprise Development, 14(3), 418-434.

Steyaert, C., \& Katz, J. (2004.) Reclaiming the space of entrepreneurship in society: Geographical, discursive and social dimensions. Entrepreneurship and Regional Development, 16, 176-196.

Timmons, J. \& Spinelli, S. (2004.) New Venture Creation: Entrepreneurship for the $21^{\text {st }}$ Century. $6^{\text {th }}$ ed., Boston, MA: McGraw Hill/Irwin.

Ucbasaran, D., Westhead, P. \& Wright, M. (2001.) The focus of entrepreneurial research: Contextual and process issues. Entrepreneurial Theory and Practice, 25, 57-80.

Weerawardena, J., \& Sullivan-Mort, G. (2006.) Investigating social entrepreneurship: A multidimensional model. Journal of World Business, 41, 21-35.

Wijweardena, H., Nanayakkara, G., \& De Zoysa, A. (2008.) The owner/mentality and the financial performance of SMEs. Journal of Small Business and Enterprise Development, 15(1), 150-161.

Wood, A., \& Joyce, P. (2000.) Owner-manager and the practice of strategic management. International Small Business Journal, 21(2), 181-195.

Zahra, S.A., Rawhouser, N.H., Bhawei, N., \& Hayton, J. (2008.) Globalization of social entrepreneurial opportunities. Strategic Entrepreneurial Journal, 2(2), 113-117.

68 NEW ENGLAND JOURNAL OF ENTREPRENEURSHIP 


\section{ABOUT THE AUTHOR}

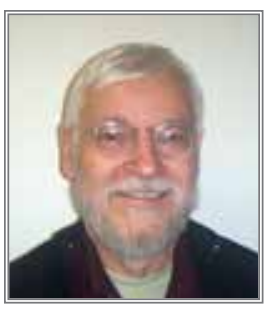

Gregory R. Berry is Chair and Professor of Management and Organization at Central Connecticut State University, teaching Entrepreneurship and Management. Dr. Berry received his PhD in Organizational Analysis from the University of Alberta in 1997. His research focus is on corporate environmental and citizenship behaviors, effective virtual teaming, and entrepreneurship 